\title{
Imidaclopride, a Potent Inhibitor of Array of Digestive Enzymes of Helicoverpa armigera (Hubner) (Lepidoptera: Noctuidae)
}

\author{
Bharat Nareshkumar ${ }^{1}$, Senigala K Jayalakshmi², Gayatridevi S ${ }^{1}$, Kuruba Sreeramulu1* \\ ${ }^{1}$ Department of Biochemistry, Gulbarga University, India \\ ${ }^{2}$ Agriculture Research Station, University of Agricultural Sciences, India
}

Submission: May 30, 2017; Published: June 28, 2017

*Corresponding author: Kuruba Sreeramulu, Department of Biochemistry, Gulbarga University, Kalaburagi-585 106, India, Tel: +91 8472 263289 ; Fax: +91 8472 263203; Email: ksramu@rediffmail.com

\begin{abstract}
Imidacloprid, the first commercialized neonicotinoid, acts by systemic and contact insecticidal activity apart from its more specific and high agonistic affinity to insect nicotinic acetylcholine receptors (nAChR) for most of the lepidoptera including Helicoverpa armigera. Effect of Imidaclopride on digestive enzymes was evaluated. Imidacloprid inhibited the growth and development of the H. armigera. Moderate changes in total protease and aminopeptidase activities were observed whereas chymotrypsin, trypsin, elastase and alkaline phosphatase activities were significantly inhibited by imidacloprid in a dose dependent manner. However, increasing pattern for all the protease were recorded at sub lethal doses of imidacloprid.
\end{abstract}

Keywords: H. armigera; Imidacloprid; Proteases; Alkaline phosphatase

Abbrevations: LD: Lethal Dose; ALP: Alkaline Phosphatase; BBMVs: Brush Border Membrane Vesicles

\section{Introduction}

The Helicoverpa armigera (Hubner) (Lepidoptera: Noctuidae) a phytophagous insect which feeds on more than hundred plant species, brought crop loss more than half the yield and annual loss of more than US $\$ 500$ million [1]. The devastating pest have developed resistance to almost all class of insecticides [2,3], have become serious constraint to crop production in Asia, Africa, Australia and Mediterranean Europe for the last four to five decades [4]. Enhanced metabolism rate in insects also plays an important role on fitness of the insect [5]. Digestive proteolytic activity in the insect gut might be the key in the adaptation of resistance against plant defensive compounds. Defensive role of lucine aminopeptidases (LAPs) have extensively studied in lepidopteran gut. The decreased utilization of food, delayed growth, reduction in survival, weight or size and reproduction of new generation adults could be due to the interference of the toxicants with amino acid metabolism, inhibited by most of the plant metabolites [6]. The H. armigera has a large multigene family for serine proteinases, which includes two main types, trypsin and chymotrypsin [7]. It has been shown [7] that the differential regulation and expression of protease enzymes in response to chronic exposure to protease inhibitors [8]. Studies were carried out with respect to the effect of imidacloprid on reproduction, fecundity, and survivorship of female in H. armigera [9]. The litrature survay shown a minimul/ lack of information regarding metabolic changes in $\mathrm{H}$. armigera under imidacloprid stress conditions which can be correlated with the other neonicotinoids and lepidopteran insect pest. Here we report the effect of imidacloprid on serine proteases, aminopeptidase and detoxification enzymes on the fitness of the H. armigera larvae.

\section{Materials and Methods}

\section{Chemicals}

Rallis India Limited, Bangalore, India, kindly provided imidacloprid. Adenosine triphosphate (ATP), adenosine diphosphate (ADP), azocasein, bovine serum albumin (BSA), 
1,4- leucine p-nitroanilide (LpNA), $\mathrm{N}$ - $\alpha$-benzoyl-DL-arginine p-nitroanilide, N-glutaryl-L-phenylalanine p-nitroanilide, p-Nitroanisole ( $p-N A$ ), phenazine methosulfate (PMS), were purchased from Sigma Aldrich (Mumbai, India). All other chemicals used were commercial products and of analytical grade of highest purity available.

\section{Insects}

The present study was carried out at International Crops Research Instituite for Semi-Arid Tropics (ICRISAT), Patancheru, Telangana State, India. $H$. armigera larvae were reared on a chickpea based semi-synthetic diet under laboratory conditions at $27 \pm 1^{\circ} \mathrm{C}, 65 \pm 5 \% \mathrm{RH}$, and $12 \mathrm{~h}$ photoperiod, obtained from the insect rearing laboratory.

\section{Bioassay}

Initial weights of third instar larvae were recorded before releasing on the diet containing different concentrations of imidacloprid $(0-600 \mu \mathrm{M})$. Three replicates for each treatment containing 10 larvae in each replication. The larvae fed with insecticide for 7 days and the final weights and mortality were receded [10].

\section{Enzyme preparations}

Imidacloprid treated and untreated larval midguts were homogenised with two volumes of $0.1 \mathrm{M}$ glycine- $\mathrm{NaOH}$ buffer $\left(\mathrm{pH} \mathrm{10.0)}\right.$, centrifuged at $8000 \times \mathrm{g}$ for $20 \mathrm{~min}$ at $4{ }^{\circ} \mathrm{C}$. The supernatants were used as enzyme source for protease assay [11].

Brush border membrane vesicles (BBMVs) were prepared by the method adopted from [12], where guts were removed from imidacloprid treated and untreated larvae were homogenised with $20 \mathrm{mM}$ Tris-HCl buffer (pH 7.5) containing 5mM EGTA, 1mM PMSF and $300 \mathrm{mM}$ mannitol, at cold condition. The homogenates were added with equal volumes of $20 \mathrm{mM} \mathrm{MgCl}_{2}$ and allowed to stand on ice for $20 \mathrm{~min}$ followed by centrifugation at $2500 \times \mathrm{g}$ for $15 \mathrm{~min}$ at $4{ }^{\circ} \mathrm{C}$. The supernatants were stand on ice where as the pelletes were resuspended with the extraction buffer and the process repeated for twice. The resulting supernatants were pooled and centrifuged at $30000 \times \mathrm{g}$ for $30 \mathrm{~min}$ at $4{ }^{\circ} \mathrm{C}$. The pellets containing BBMVs obtained were suspended in minimum volumes of extraction buffer for aminopeptidase assay.

\section{Effect of imidacloprid on gut proteases}

Aminopeptidase activity was measured by incubating brush border membrane vesicles (BBMVs) from imidacloprid fed and unfed larvae using leucine p-nitroanilide (LpNA) as a substrate. Reaction mixture consisted of $50 \mu \mathrm{L}$ of enzyme, $20 \mu \mathrm{L}$ of $2 \mathrm{mM}$ substrate and $630 \mu \mathrm{L}$ of Glycine-NaOH buffer (pH 10.0) incubated for $20 \mathrm{~min}$ at $37^{\circ} \mathrm{C}$. The reaction mixtures were centrifuged at $5000 \times \mathrm{g}$ for $15 \mathrm{~min}$ after adding $300 \mu \mathrm{L}$ of $30 \%$ acetic acid. The absorbance was measured at $410 \mathrm{~nm}$ [11].
Elastase activity was measured similarly as aminopeptidase, except using $\mathrm{N}$-succinyl-alanine-alanine-alanine p-nitroanilide (SAAApNA), as a substrate. One unit of enzyme activity was defined as the micromoles of $\mathrm{p}$-nitroaniline released per minute per milligram of gut protein [11].

Total protease activity was measured by using $1 \%$ azocasein as a substrate in $0.1 \mathrm{M}$ glycine- $\mathrm{NaOH}$ buffer ( $\mathrm{pH} 10.0$ ). $100 \mu \mathrm{L}$ of gut extract was incubated with $500 \mu \mathrm{L}$ of substrate and incubated for $30 \mathrm{~min}$ at $37{ }^{\circ} \mathrm{C}$. Then add $200 \mu \mathrm{L}$ of $5 \%$ TCA followed by centrifugation at $5000 \times \mathrm{g}$ for $15 \mathrm{~min}$. Equal volumes of $1 \mathrm{~N} \mathrm{NaOH}$ were added to the supernatants to read the absorbance at 450 $\mathrm{nm}[11]$.

Chymotrypsin and trypsin activities were determined by using $30 \mu \mathrm{L}$ of $1 \mathrm{mM}$ N-glutaryl-L-phenylalanine p-nitroanilide and $10 \mu \mathrm{L}$ of $1.2 \mathrm{mM} \mathrm{N}$ - $\alpha$-benzoyl-DL-arginine-p-nitroanilide as substrates, respectively. Enzyme $(50 \mu \mathrm{L})$ mixed with respective substrates and $0.1 \mathrm{M}$ glycine- $\mathrm{NaOH}$ buffer (pH 10.0) (to make $700 \mu \mathrm{L}$ of final volume), was incubated for $20 \mathrm{~min}$ at $37^{\circ} \mathrm{C}$ and then adds $300 \mu \mathrm{L}$ of $30 \%$ acetic acid and stand for $10 \mathrm{~min}$. The absorbance was measured at $410 \mathrm{~nm}$ after centrifugation of the samples at $8000 \times \mathrm{g}$ for $10 \mathrm{~min}$. Amount of enzyme catalyzing the hydrolysis of $1 \mu \mathrm{M}$ substrate per minute at $37^{\circ} \mathrm{C}$, was defined as one unit of enzyme activity [13].

\section{Alkaline phosphatase assay}

Alkaline phosphatase activity was measured using p-nitrophenyl phosphate (p-NP) as substrate [13]. In brief, assay mixture consisted $50 \mu \mathrm{L}$ of $0.1 \mathrm{mM} \mathrm{p}-\mathrm{NP}, 900 \mu \mathrm{L}$ of $0.1 \mathrm{M}$ Tris- $\mathrm{HCl}$ buffer ( $\mathrm{pH} 8.6$ ) and $50 \mu \mathrm{L}$ of enzyme, change in the absorbance was measured at $405 \mathrm{~nm}$ for $3 \mathrm{~min}$. Protein concentrations for all the enzymes assays were measured using bovine serum albumin (BSA) as a standard [14].

\section{Statistical analysis}

Data were subjected to One-way Analysis of Variance (ANOVA) using Genstat (14th edition, Version 14.1.0.5943, VSN International Ltd, United Kingdom) software to judge the significance of differences between the treatments by F-test, while the treatment means were compared by least significant difference (LSD) at $\mathrm{p}<0.05$. Ducan's Multiple Range Test (DMRT) was used to know the differences between treatments. LD50 values were determined by using EPA PROBIT analysis program (Version 1.5).

\section{Results}

\section{Bioassay}

Imidacloprid inhibited the growth of third instar H. armigera larvae in a dose-dependent manner. There was $\sim 67.5 \%$ larval growth inhibition and $73.33 \%$ reduction in survival rate observed. $\mathrm{LD}_{50}$ value for the insecticide was found to be $531.24 \mu \mathrm{M}$ (95\% confidence limit) (data not shown). 


\section{Effect of imidacloprid on gut proteases}

Dose dependent response was observed in gut protease profile of larvae fed with insecticide compared with the control larvae for $24 \mathrm{~h}$. A significant decrease in of chymotrypsin (57.14\%), trypsin $(57.07 \%)$ and total proteases (14.81\%) were observed at $600 \mu \mathrm{M}$ of imidacloprid. The activities in the control larvae were found to be $0.133 \pm 0.008 \mathrm{U} / \mathrm{mg}, 2.05 \pm 0.190 \mathrm{U} / \mathrm{mg}$ and $0.027 \pm 0.001 \mathrm{UA}$, respectively, and the activities of imidaclopride
$(600 \mu \mathrm{M})$ treated larvae were found to be $0.057 \pm 0.005 \mathrm{U} / \mathrm{mg}$, $0.88 \pm 0.008 \mathrm{U} / \mathrm{mg}$ and $0.023 \pm 0.005 \mathrm{UA}$, respectively (Table 1 ). Elastas $(0.37 \pm 0.008$ to $0.18 \pm 0.049 \mathrm{U} / \mathrm{mg})$ and aminopeptidase $(0.13 \pm 0.002-0.11 \pm 0.003 \mathrm{U} / \mathrm{mg})$ activities were also inhibited significantly by $51.35 \%$, and $15.38 \%$, respectively, compared with the control larvae, in a dose dependent manner, of the larvae fed with increasing concentrations of imidacloprid (0$600 \mu \mathrm{M})$ (Table 1).

Table 1: Dose dependent response of protease enzymes in $H$. armigera fed on diet containing fimidacloprid. The values were represented as mean $\pm S E(n=3)$.

\begin{tabular}{|c|c|c|c|c|c|}
\hline $\begin{array}{c}\text { Dose } \\
(\boldsymbol{\mu} \mathbf{M})\end{array}$ & $\begin{array}{c}\text { Chymotrypsin } \\
(\mathbf{U} / \mathbf{m g})\end{array}$ & $\begin{array}{c}\text { Trypsin } \\
(\mathbf{U} / \mathbf{m g})\end{array}$ & $\begin{array}{c}\text { Total protease } \\
(\mathbf{U A})\end{array}$ & $\begin{array}{c}\text { Elastase } \\
\mathbf{( U / m g} \mathbf{m}\end{array}$ & $\begin{array}{c}\text { Aminopeptidase } \\
(\mathbf{U} / \mathbf{m g})\end{array}$ \\
\hline 0 & $0.133 \pm 0.008 \mathrm{c}$ & $2.05 \pm 0.190 \mathrm{c}$ & $0.027 \pm 0.001 \mathrm{bcd}$ & $0.37 \pm 0.008 \mathrm{e}$ & $0.13 \pm 0.002 \mathrm{ab}$ \\
\hline 400 & $0.127 \pm 0.003 \mathrm{c}$ & $1.52 \pm 0.032 \mathrm{~b}$ & $0.031 \pm 0.001 \mathrm{~d}$ & $0.35 \pm 0.058 \mathrm{de}$ & $0.16 \pm 0.005 \mathrm{~b}$ \\
\hline 450 & $0.117 \pm 0.008 \mathrm{c}$ & $1.45 \pm 0.127 \mathrm{~b}$ & $0.026 \pm 0.006 \mathrm{bcd}$ & $0.32 \pm 0.045 \mathrm{~cd}$ & $0.14 \pm 0.005 \mathrm{~b}$ \\
\hline 500 & $0.113 \pm 0.004 \mathrm{bc}$ & $1.37 \pm 0.054 \mathrm{~b}$ & $0.025 \pm 0.007 \mathrm{ab}$ & $0.30 \pm 0.142 \mathrm{bc}$ & $0.14 \pm 0.002 \mathrm{ab}$ \\
\hline 550 & $0.097 \pm 0.005 \mathrm{~b}$ & $0.94 \pm 0.026 \mathrm{a}$ & $0.024 \pm 0.001 \mathrm{a}$ & $0.26 \pm 0.001 \mathrm{~b}$ & $0.13 \pm 0.013 \mathrm{ab}$ \\
\hline 600 & $0.057 \pm 0.005 \mathrm{a}$ & $0.88 \pm 0.008 \mathrm{a}$ & $0.023 \pm 0.005 \mathrm{a}$ & $0.18 \pm 0.049 \mathrm{a}$ & $0.11 \pm 0.003 \mathrm{a}$ \\
\hline
\end{tabular}

Column values followed by same letters are not significantly different from each other at $p<0.05 \%$.

\section{Alkaline phosphatase activity (ALP)}

Significant dose-dependent reduction of alkaline phosphatase activity in the larvae fed on diet containing increasing concentration of imidacloprid $(0-600 \mu \mathrm{M})$. The decline was measured to be $0.33 \pm 0.0004$ to $0.13 \pm 0.001 \mu \mathrm{M} / \mathrm{min} /$ mg of protein (Figure 1).

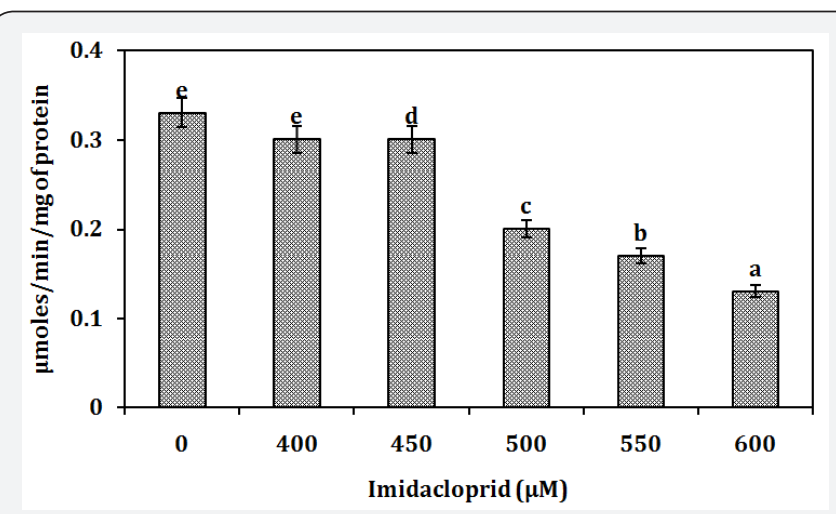

Figure 1: Dose dependent response of alkaline phosphatase in $\mathrm{H}$. armigera fed on diet containing imidacloprid. The values were represented as the mean $\pm S . D$. $(n=3)$ (significantly different from control, $p<0.05$ ).

\section{Discussion}

Proteases play a vital role in the proper development of insects as they hydrolyze the peptide bonds to liberate free amino acids by the action of endopeptidases and exopeptidases, as they are needed for the growth, survival and reproduction [15]. The decreased activities of chymotrypsin, trypsin and total protease confers to the antifeedant nature of imidacloprid where the larvae unable to metabolise the diet provided for its survival, growth, and reproduction.

Insects when exposed to protease inhibitors alter their midgut composition by monitoring the proteases secretion [16]. Studies have shown that the food, temperature, and acidity are key factors responsible for production of energy needed for larval development. The food containing imidacloprid directly affected the feeding behaviour of the insect thereby leading to the reduced body weight and delayed growth in a dose dependent pattern (data not shown). Aminopeptidases, catalyses the amino acids hydrolysis from $\mathrm{N}$-terminus of the peptides and proteins was moderately inhibited at higher concentration of insecticide. The physiological condition of insects are related to levels of alkaline phosphatase which can also reflects digestion, absorption, and positive transport of nutrients in the midgut [17]. Tyrosine 0-phosphate was shown to be the natural substrate for Alkaline phosphatase [18] in Drosophila. Decreased levels of ALP activities provides the lower levels of tyrosine, precursor of dopamine and octopamine, play a vital role in regulation of juvenile hormone $(\mathrm{JH})$, and 20-hydroxyecdysone (20E) [18]. The decreased level of alkaline phosphatase activity in response to increased concentrations of imidacloprid indicates insecticide's harmful effect on insect's digestive system and development.

\section{Conclusion}

Our results demonstrate that imidacloprid acts as potent protease inhibitor by inhibiting elastase, aminopeptidase, chymotrypsine, trypsine, total proteases and ALP. 


\section{References}

1. King ABS (1994) Heliothis/Helicoverpa (Lepidoptera: Noctudae). In: Mathews GA and Tunstall JP (Eds.), Insect Pest of Cotton. CAB International, UK, pp. 39-106.

2. Akbar SMD, Ravindra MA, Sharma HC, Sreeramulu K (2014) Mitochondrial P-Glycoprotein ATPAse contributes to insecticide resistance in the cotton bollworm, Helicoverpa armigera (Noctuidae: Lepidoptera). Cell Biochem Biophys 70(1): 651-660.

3. Srinivas, R, Udikeri SS, Jayalakshmi SK, Sreeramulu K (2004) Identification of factors responsible for insecticide resistance in Helicoverpa armigera. Comp Biochem Physiol C Toxicol Pharmacol 137(3): 261-269.

4. Han Y, Wu S, Li Y, Jian-Wei L, Campbell PM, et al. (2012) Proteomic and molecular analyses of esterases associated with monocrotophos resistant in Helicoverpa armigera. Pestic Biochem Physiol 104(3): 243251.

5. Ahmad M, McCaffery AR (1991) Elucidation of detoxication mechanisms involved in resistance to insecticides in the third instar larvae of a field-selected strain of Helicoverpa armigera with the use of synergists. Pestic Biochem Physiol 41: 41-52.

6. Lomate PR, Jadhav BR, Giri AP, Hivrale VK (2013) Alterations in the Helicoverpa armigera midgut digestive physiology after ingestion of pegion pea inducible leucine aminopeptidase. PLoS ONE 8(9): e74889.

7. Gatehouse LN, Shannon AL, Burgess EP, Christeller JT (1997) Characterization of major midgut proteinase cDNAs from Helicoverpa armigera larvae and changes in gene expression in response to four proteinase inhibitors in the diet. Insect Biochem Mol Biol 27(11): 929944.

8. Gatehouse LN, Christeller JT, Gatehouse HS, Zou XY (2002) A strong inhibitor of chymotrypsin/elastase is highly antimetabolic to helicoverpa armigera larvae, New Zealand Plant Protect 55: 421-428.

9. Ahmad S, Ansari MS, Ahmad N (2013) Acute toxicity and sublethal effects of the neonicotinoid imidacloprid on the fitness of Helicoverpa armigera (Lepidoptera: Noctuidae). Int J Trop Insect Sci 33(4): 264275.

10. Akbar SMD, Sharma HC, Jayalakshmi SK, Sreeramulu K (2012) Methylparathion- and Carbofuran-induced mitochondrial dysfunction and oxidative stress in Helicoverpa armigera (Noctuidae: lepidoptera). Pestic Biochem Physiol 103(1): 31-37.

11. Visweshwar R, Sharma HC, Akbar SMD, Sreeramulu K (2015) Elimination of gut microbes with antibiotics confers resistance to Bacillus thurangenesis toxin proteins in Helicoverpa armigera (Hubner). Appl Biochem Biotech 177(8): 1621-1637.

12. Abdul-Rauf M, Ellar DJ (1999) Isolation and Characterization of Brush Border Membrane Vesicles from Whole Aedes aegypti Larvae, J Invertebr Pathol 73(1): 45-51.

13. Dean RL (2002) Kinetic studies with alkaline phosphatase in the presence and absence of inhibitors and divalent cations. Biochem Mol Biol Edu 30(6): 401-407.

14. Lowry OH, Rosenbrough NJ, Farr AL, Randal AJ (1951) Protein measurements with the folin phenol reagent. J Biol Chem 193: 265275.

15. Mahdavi A, Ghadamyari M, Sajedi RH, Sharifi M, Kouchaki B (2013) Identification and partial characterization of midgut proteases in the lesser mulberry pyralid, Glyphodes pyloalis. J Insect Sci 13(81): 1-11.

16. Hosseininejad AS, Naseri B, Razmjou J (2015) Comparative feeding performance and digestive physiology of Helicoverpa armigera (Lepidoptera: Noctuidae) larvae-fed 11 corn hybrids. J Insect Sci 15(12): 179

17. Miao YG (1988) Study on the alkaline phosphatase in the midgut of domestic silkworm, Bombyxmori. Acta Sericologica Sinica 14(3):154158.

18. Wang Z, Liu S, Yang B, Liu Z (2011) Characterization of soluble and membrane-bound alkaline phosphatase in Nilaparvata lugens and their potential relation to development and insecticide resistance. Insect Biochemistry and Physiology 78(1): 30-45.

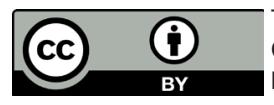

This work is licensed under Creative

\section{Your next submission with Juniper Publishers will reach you the below assets}

- Quality Editorial service

- Swift Peer Review

- Reprints availability

- E-prints Service

- Manuscript Podcast for convenient understanding

- Global attainment for your research

- Manuscript accessibility in different formats

( Pdf, E-pub, Full Text, Audio)

- Unceasing customer service

Track the below URL for one-step submission https://juniperpublishers.com/online-submission.php 